\title{
METODE ISTINBATH HUKUM NAFKAH IDDAH TALAK BAIN MENURUT SYAFI'IYYAH
}

\author{
Tiyan Hasanah \\ Institut Agama Islam Negeri (IAIN) Metro \\ Email: tiyanhasanah98@gmail.com
}

\begin{abstract}
Iddah is one of the obligations of a wife who is divorced by her husband. During iddah, the wife has the right to get a place to live and provide a living, that is what applies to talak raj'i and not to a wife who is divorced ba in. This research is a library research. Nafkah Iddah the details of which are not explicitly explained in the Al-Qur'an and Hadith. This has led to differences of opinion among the schools of thought. Shafi iyyah uses mafhum mukhalafah as an istinbath method in understanding Surah ath-Talaq Verse 6 and uses the ahad Hadith from Fatimah bint Qais as the basis for the absence of iddah talaq bain for wives who are not pregnant. The use of mafhum mukhalafah by Shafi iyyah affects the rule of law. According to Syafi iyyah, pregnancy is a requirement or qayid for the obligatory support for the wife who has been bullied, which means that if there is no pregnancy, it is not obligatory to provide for the wife who is wronged.
\end{abstract}

Keywords: Legal Istinbath, Iddah, Syafi'iyyah.

\section{A. Pendahuluan}

Perceraian adalah peristiwa hukum yang berakibat putusnya ikatan perkawinan antara suami istri. Sebagai suatu peristiwa hukum, perceraian bukan hanya dipandang sebagai putusnya ikatan perkawinan saja, tetapi mengandung akibat hukum yuridis, dan akibat hukum materi. Dari aspek yuridis, perceraian mengakibatkan istri tidak terikat perkawinan dengan mantan suami, dan setelah habisnya masa iddah dapat menikah dengan pria lain. Adapun akibat hukum materi pengadilan dapat rnewajibkan kepada bekas suami untuk memberikan biaya hidup untuk bekas istri selama masa iddah. ${ }^{1}$

Masa iddah diwajibkan pada semua wanita yang berpisah dari suaminya dengan sebab talak, khulu' (gugat cerai), faskh atau ditinggal mati, dengan syarat sang suami telah melakukan hubungan suami istri dengannya atau telah diberikan kesempatan dan kemampuan yang cukup untuk melakukannya. Salah satu bentuk ketentuan dalam hukum perceraian adalah kewajiban memberi nafkah iddah bagi istri yang ditalak. Para ahli fiqh sepakat bahwa perempuan yang ditalak raj'i masih berhak mendapat nafkah dan tempat tinggal. ${ }^{2}$

Yang menyebabkan terjadinya perbedaan pendapat di kalangan fuqoha dalam masalah nafkah selama masa iddah talak bain , karena ada perbedaan metode istinbath yang digunakan, dalam hal ini karena adanya perbedaan riwayat tentang hadis Fatimah binti Qais dan adanya pertentangan antara hadis tersebut dengan lahirnya

${ }^{1}$ Abdul Manan, Aneka Masalah Hukum Perdata Islam di Indonesia, (Jakarta: Kencana, 2017), h. 21. 2 Sayyid Sabiq, Fiqih Sunnah, Terj. Nor Hasanuddin, (Jakarta: Pena Pundi Aksara, 2006), h. 229. 
ayat al-Qur'an (At-Thalaq : 6). ${ }^{3}$ Oleh karena itu para fuqoha menggunakan pendekatan lain sebagai acuan dalam menetapkan hukum yang tidak dijelaskan secara tegas dalam Al-Quran atau Hadis,baik berupa qiyas, 'urf maupun metode istinbath hukum lainnya.

Iddah secara istilah adalah tenggang waktu yang ditetapkan oleh Allah setelah perceraian, dan wajib hukumnya kepada seorang wanita untuk menunggu pada masa itu dengan tidak diperbolehkan menikah sehingga habis waktunya. ${ }^{4}$ Masa (waktu) menunggu dalam iddah ditetapkan oleh syariat Islam dan hanya berlaku bagi wanita yang sudah dicampuri oleh suaminya, sedangkan wanita yang diceraikan suaminya sebelum bercampur dengan suami tidak ada iddah baginya.

Iddah dapat dikelompokkan dalam empat macam. Pertama, Iddah istri yang berhaid Syafi yyah mengatakan Quru' berarti masa suci. Setengah masa suci juga dihitung satu persucian yang sempurna. Apabila suami menalak istrinya dalam keadaan suci dan kemudian si istri haid, masa iddahnya habis setelah menjalani dua masa suci yang lain dan mulai masuk haid ketiga. Apabila dia mentalak istrinya dalam kondisi haid, dia mesti menjalani 'iddah selama tiga persucian yang sempurna. Iddahnya selesai begitu haid keempat habis. Kedua, Iddah istri tidak berhaid. Perempuan yang tidak haid ada tiga, yaitu masih kecil (belum sampai umur); sudah sampai umur, tetapi belum pernah haid; sudah pernah haid, tetapi sudah tua. sehingga sudah tidak haid lagi (menopouse). ${ }^{5}$ Ketiga, Iddah perempuan yang hamil. Untuk Wanita iddah bukan karena ditinggal mati Suaminya, jika dalam keadaan hamil, maka iddahnya dengan melahirkan anak yang bisa dihubungkan nasabnya pada suami yang memiliki iddah tersebut. ${ }^{6}$ Keempat, Iddah istri yang ditinggal mati suami. Para ulama mazhab sepakat bahwa iddah wanita yang ditinggal wafat suaminya, sedangkan dia tidak hamil, adalah empat bulan sepuluh hari, baik wanita tersebut sudah dewasa maupun masih anak-anak, dalam usia menopause atau tidak, sudah dicampuri atau belum. ${ }^{7}$

Para ahli fiqh sepakat bahwa perempuan yang ditalak raj'i masih berhak mendapat nafkah dan tempat tinggal. Akan tetapi, para ahli fiqih masih berselisih tentang perempuan yang ditalak bain. Imam Syafi'i berkata: Diriwayatkan dari Abu Salamah dan Fathimah binti Qais bahwa Abu Amr bin Hafshah menjatuhkan talak $b a^{\prime}$ in kubra sementara istrinya berada di negeri Syam. Maka la mengutus wakil kepada istrinya dengan membawa sya'ir (salah satu jenis gandum) dan si istri memarahi suaminya (karena hanya mengirimkan makanan seperti itu).Maka ia berkata, "Demi Allah, tidak ada kewajiban kami atasmu sedikitpun!"Lalu la datang kepada Rasulullah SAW dan menyebutkan hal itu, maka beliau bersabda,“Tidak ada hak

3 Abul Wahid Muhammad Ibnu Rusyd, Bidayatul Mujtahid Wa Nihayatul Muqtasid, Terj. Imam Ghazali Said dan Ahmad Zaidun, (Jakarta: Pustaka Amani, 2007), h. 615.

4 Abu Malik Kamal bin as-Sayyid Salim, Ensikiopedi Fiqih Wanita, Terj. Beni Sarbeni, (Bogor: Pustaka Ibnu Katsir, 2009), h. 418.

${ }^{5}$ Boedi Abdullah, Perkawinan dan Perceraian Keluarga Muslim, (Bandung: Pustaka Setia, 2013), h. 253.

${ }^{6}$ Gus Arifin dan Sundus Wahidah, Ensikiopedia Fikih Wanita: Pembahasan Lengkap A-Z Fikih Wanita dalam Pandangan Empat Mazhab, (Jakarta: Elex Media Komputindo, 2018), h. 259.

7 Muhammad Jawad Mughniyah, Fiqih lima mazhab: Ja'fari, Hanafi, Maliki, Syafi'i, Hambali, Terj. Masykur A.B., (Jakarta: Lentera 2012), h. 469. 
nafkah bagimu padanya. ${ }^{8}$

Berdasarkan kutipan di atas, alasan yang dikemukakan Syafi yyah tentang tidak adanya nafkah bagi istri yang ditalak bain dan tidak sedang hamil adalah Hadis dari fatimah binti Qais yang ditalak bain oleh suaminya. Dalam Hadis tersebut disebutkan bahwa Rasulullah Saw, tidak menetapkan nafkah bagi Fatimah binti Qais.

\section{B. Pembahasan}

\section{B.1. Biografi Mazhab Syafi i}

Mazhab Syâfi'î dibangun oleh Abû Abdillah Muhammad Idrîs Asy-Syâfi'i, lahir di desa Gaza pada tahun 150 H. Pada umur dua tahun Imam Syafi'i dibawa ibunya Fatimah binti Ubaidillah Al-Azdiyah ke Asqalan, kemudian pada umur 10 tahun Imam Syafi i dibawa ke Mekkah. Imam Syafi'i membangun mazhabnya dengan mengkombinasikan mazhab Hijaz (ahli al-Hadis) dan mazhab'Iraq (ahli al-Ra'y).' Halaqah Asy-Syâfi'î di Masjid Haram menawarkan konsep-konsep baru mengenai metodologi ilmu fiqih dan menawarkan pendapat-pendapat baru yang segar. Pada tahun 195 H. Imam Syafi i pergi untuk kedua kalinya ke 'Irâq dan membuka halaqah di Masjid al-Garbî Baghdad. Setelah meletakkan kerangka besar mazhabnya di sini selama dua tahun ia kembali ke Mekkah. Mazhab inilah yang disebut al-qaul al-qadim. Setahun atau dua tahun kemudian tepatnya pada tahun $199 \mathrm{H}$ ia kembali ke Irâq untuk ketiga kalinya selama satu tahun dan dua bulan kemudian ia berangkat ke Mesir pada akhir tahun $199 \mathrm{H}$ di Mesir, ia memperbaharui mazhabnya sehingga langkah-langkahnya yang kedua ini dikenal dengan nama al-qaul al-jadid. ${ }^{9}$

Imam Syafi i meneliti dan mengkaji karya-karya ilmiah dan rasional dalam berbagai disiplin ilmu, agar dapat memilih metode yang tepat sebagai dasar bagi mazhab fiqih barunya. Ia mulai menyusun kaidah-kaidah dan ushul fiqih untuk memposisikan dirinya secara tepat di antara mazhab tradisional dan mazhab rasional. ${ }^{10}$

Imam Syafi'i terus menyebarkan mazhab baru di Iraq dengan tekun dan sungguh-sungguh selama 2 tahun. Bahkan telah mempunyai pengikut setia dan kader-kader penerusnya, seperti Ahmad bin Hanbal, az-Za'farani,al-Karabisi, dan Abu Tsaur. Selama di Baghdad, ia berhasil menulis kitab fiqih yang diberi judul alHujjah. Ibnu Hajar mengutip pendapat al-Baihaqi yang menyebutkan bahwa kitab alHujjah karya Syaf'i i disebarkan oleh az-Za'farani. Selain itu, ada juga karya-karya Syafi'i lainnya yang disebarkan oleh murid selain az-Za'farani, seperti kitab as-Sair yang diriwayatkan oleh Abu Abdurrahman Ahmad bin Yahya asy-Syafí'i. Dalam kitab Kasyf azh-Zhunûn, disebut kan bahwa kitab al-Hujjah karya Syafi'i adalah kitab fiqih yang berjilid besar yang ditulis di Iraq. ${ }^{11}$

Fatwa-fatwa yang dikeluarkan oleh Imam Syafi'i pada periode pertumbuhan Mazhab di Baghdad disebut qaul qadim dan banyak tertuang dalam Kitab al-Risalah al-

${ }^{8}$ Muhammad bin Idris asy-Syafi i, Mukhtashar Kitab al-Umm..., h. 602.

${ }^{9}$ Abdul Hadi Muthohhar, Pengaruh Mazhab Syafi i di Asia Tenggara, (Semarang: Aneka Ilmu, 2003), h. 14.

${ }^{10}$ Ahmad Nahrawi Abdus Salam, Ensiklopedia Imam Syafi'i, al-Imam al-Syafi i Mazdhabihi al-Qadim wa al-Jadid), Terj. Usman Sya`roni, (Jakarta: Mizan Publika, 2008), h. 174.

11 Ahmad Nahrawi Abdus Salam, Ensiklopedia Imam Syafi'i..., h. 175. 
Qadimah. Adapun fatwa-fatwa yang dikeluarkan setelah ia berada di Mesir disebut qaul jadid. Fatwa-fatwa yang dikeluarkan oleh Imam Syafi'i setelah berada di Mesir disebut dalarn Risalah al-Jadidah yang dikenal dan beredar hingga sekarang. ${ }^{12}$

Kitab Risalah al-Jadidah (qaul jadid) merupakan kitab ushul fikih yang memuat kaidah-kaidah yang secara taat asas diaplikasikan oleh Asy-Syafi'i dalam melaksanakan ijtihadnya dalam menetapkan suatu hukum. Selain itu, qaul jadid yang dikemukakan oleh Asy-Syafi'i ini juga terdapat dalam Kitab al-Umm, al-Amali, al-Imla ' dan lain-lain. Fatwa-fatwa qaul jadid ini diriwayatkan oleh enam orang sahabat Imam Syafi'i di Mesir, yaitu Imam al-Buwaitihi (w.231), Harmalah (w. 241), al-Rabi' al-Jizi (w. 257), Yunus Ibn Abd. al-Ala (w. 264), al-Muzani (w. 264), dan al-Rabi' al-Muradi (w. 271). Melalui mereka inilah Mazhab asy-Syafi'i berkembang ke berbagai wilayah Islam di seluruh dunia. ${ }^{13}$ Dan di antara para perawi pendapat-pendapat dan fatwa Imam Syafi'i saat di Iraq (qaul qadim) adalah Imam Ahmad Ibn Hanbal (W 241 H), Abu Tsaur Ibrahim Ibn Khalid (W 240 H), Abu 'Ah al-Hasan Ibn Muhammad aI-Za'farany (W 248H) dan Abu ‘Aly al-Husain Ibn ‘Aly al-Karabisy (W 248H).

Mazhab Syafi i berkembang dikembangkan oleh murid-muridnya ke seluruh dunia. Adapun murid-murid Imam Syafi'i di antaranya adalah sebagai berikut: Di mekkah Abu Bakar Al-Humaidi, Ibrahim bin Muhammad Al-Abbas, Abu Bakar bin Muhammad bin idris, Musa bin Abi Al-Jarud, di Baghdad: Al-Hasan As-Sabah AzZa farani, Al-Husain bib Ali Al-Karabisi, Abu Thur Al-Kulbi dan Ahmad bin Muhammad Al-Asy`ari. Di Mesir: Harmalah bin Yahya, Yusuf bin Yahya al-Buwaiti, Ismail bin Yahya al-Mizani, Muhammad bin Abdullah bin Abdul Hakam dan ArRabi in Sulaiman Al-Jizi.14

Mazhab Syafi'i sekarang diikuti di Mesir, Palestina, (juga di beberapa tempat di Syria dan Lebanon, Irak, dan India), Muangthai, Malaysia, dan Indonesia. ${ }^{15}$ Imam Syafi'i mujtahid yang pertama kali mengemukakan qiyas sebagai dasar penggalian hukum. Para Fuqoha sebelumnya membahas tentang ra'yu tanpa menentukan batasbatasanya dan tidak menentukan batasan $r a^{\prime} y u$ yang shahih dan yang tidak shahih. Imam Syafi'i adalah tokoh dan ulama besar dalam bidang Ushul Fiqh. Jasa besarnya terletak pada keberhasilannya mensistimasikan dasar-dasar teori fiqh (teori-teori yurisprudensi Islam) menjadi sebuah disiplin ilmu yang dikenal dengan Ushul Fiqh. Ijma dan qiyas menurut Imam Syafi i merupakan sumber hukum tambahan setelah Al-Qur'an dan Hadis.

\section{B.2. Metode Istinbath Hukum Syafi yyah}

Istinbât dari segi etimologi berasal dari kata nabata- yanbutu-nabtun yang berarti "air yang pertama kali muncul pada saat seseorang menggali sumur". Kata kerja tersebut kemudian dijadikan bentuk transitif, sehingga menjadi anbata dan istinbâta, yang berarti mengeluarkan air dari sumur (sumber tempat air tersembunyi). ${ }^{16}$

\footnotetext{
${ }^{12}$ Abdul Manan, Pembaruan Hukum Islam di Indonesia, (Jakarta: Kencana, 2017), h. 17.

13 Ibid.

${ }^{14}$ Ahmad As-Syurbasi, Sejarah dan Biografi Imam Empat Mazhab..., h. 151-152.

15 Fauzi, Sejarah Hukum Islam, (Jakarta: Kencana, 2018), h. 65.

16 Rahmawati, Istinbât Hukum Teungku Muhammad Hasbi Ash-Shiddieqy, (Yogvakarta: Deepublish,
} 2015), h. 29. 
Istinbath hukum merupakan sebuah cara pengambilan hukum dari sumbernya. Perkataan ini lebih populer disebut dengan metodologi penggalian hukum. Metodologi, menurut seorang ahli dapat diartikan sebagai pembahasan konsep teoretis berbagai metode yang terkait dalam suatu system pengetahuan. Jika hukum Islam dipandang sebagai suatu sistem pengetahuan, maka yang dimaksudkan metodologi hukum Islam adalah pembahasan konsep dasar hukum Islam dan bagaimanakah hukum Islam tersebut dikaji dan diformulasikan. ${ }^{17}$

Metode istinbat hukum Syafi yyah didasarkan pada pemikiran Imam Syafi i yang menyerap berbagai karakteristik mazhab fiqh yang berbeda-beda dari berbagai kawasan, antara lain Makah, Yaman, Irak dan Mesir. Penyerapan tersebut pada akhirnya mempengaruhi alur pemikiran dan ijtihad hukum yang dihasilkan Syafi yyah. Perjalanan studi Imam Syafi i menghasilkan rekonsiliasi atas berbagai perbedaan yang muncul di tiap daerah dan kemudian menghasilkan perpaduan menjadi mazhab baru.

Metode ijtihad yang digunakan Syafi yyah dalam menggali hukum didasarkan pada empat sumber hukum sebagai berikut: Kitab Suci Al-Qur'an, Hadits-hadits atau Sunnah Nabi, Ijma' (kesepakatan Imam-imam Mujtahid dalam satu masa), Qiyas (perbandingan antara yang satu dengan yang lainnya).18

Operasional penggunaan qiyâs dimulai dengan mengeluarkan hukum yang ada pada teks (asli). Cara ini memerlukan kerja nalar yang luar biasa dan tidak cukup hanya dengan pemahaman makna lafazh saja. Tetapi harus sesuai dengan prosedur istinbath Hingga kemudian seorang mujtahid menemukan illat disyariatkannya hukum tersebut. Selanjutnya mujtahid meneliti dan mencari serta menetapkan ada atau tidaknya illat tersebut pada kasus yang belum ada naș hukumnya. Baru kemudian, setelah benar-benar terbukti bahwa pada far' $u$ (kasus cabang) terdapat illat yang ada sama pada hukum asal, maka status hukum yang ada bisa dijalarkan pada far'u dengan jalan analogi (qiyâs). Dengan demikian, status hukum far'u (cabang) sama dengan hukum asli yang memang dan awal bersumber dan teks al-Qur'an dan Hadis.

Salah satu penyebab perbedaan dalam memahami dalil nash adalah perbedaan metode istinbât yang digunakan. Hal ini terlihat dalam perbedaan dalam memahami dalil nash yang dijadikan dasar dalam penetapan nafkah terhadap istri pada masa iddah talak bain.

\section{B.3. Nafkah Iddah Talak Bain Menurut Syafi'iyyah}

Nafkah iddah bagi istri yang ditalak bain merupakan masalah hukum yang tidak ditemukan dalil nash secara qoth'i (tegas), sehingga memunculkan perbedaan pandangan ulama dalam penetapan hukumnya melalui ijtihad. Dalam proses berijtihad diperlukan penggalian hukum (istinbât) sesuai dengan metode yang digunakan masing-masing ulama mazhab. Perbedaan metode dapat berimplikasi pada perbedaan produk hukum, termasuk dalam nafkah iddah talak bain.

17 Ghufron A. Mas'adi, Pemikiran Fazlur Rahman tentang Metodologi Pembaharuan Hukum Islam, (Jakarta: Raja Grafindo Persada, 1998), h. 2.

18 Sirajuddin Abas, Sejarah dan Keagungan Madzhab Syafi'i, (Jakarta: Pustaka Tarbiyah Baru, 2007), h. 70 . 
Dalil hukum yang disepakati oleh jumhur ulama adalah Al-Quran, sunnah (hadis), ijma, dan qiyas. Sedangkan yang tidak disepakati (al-mukhtalaf fiha) yaitu selain yang empat, seperti istihsan, istislah (maslahat mursalah), sadd zari ah, istishab, urf, mazhab sahabiy, dan syar' $u$ man qablana. ${ }^{19}$

Perbedaan pendapat ulama mazhab dalam memahami dalil hukum dan kehujjahan metode istinbât yang digunakan berpengaruh terhadap produk hukum yang ditetapkan. Hal ini terlihat dari perbedaan pendapat antara Syafi iyyah dan Hanafiyah dalam masalah nafkah iddah talak bain. Menurut Hanafiyah istri yang ditalak, baik talak raj i maupun bain, tetap berhak memperoleh nafkah dan tempat tinggal. Dalam hal ini, Hanafiyah tidak mempertimbangkan jenis talak kepada istri, dan kehamilan sebagai faktor yang menyebabkan perbedaan nafkah.

Adapun Syafi iyyah dalam masalah nafkah kepada istri yang ditalak membedakannya dalam tiga kategori, yaitu istri yang ditalak raj $i$, istri yang ditalak bain dalam keadaan hamil, dan istri yang ditalak bain dalam keadaan tidak hamil. Terhadap istri yang ditalak raj i, Syafi iyyah berpendapat istri tersebut berhak memperoleh nafkah dan tempat tinggal. Pendapat Syafi iyyah dalam hal ini sama dengan pendapat Hanafiyyah. Bagi istri yang ditalak bain dalam keadaan hamil, menurut Syafi iyyah tetap berhak memperoleh tempat tinggal dan nafkah. Pendapat ini juga sama dengan Hanafiyyah, sedangkan bagi istri yang ditalak baik dalam keadaan tidak hamil, menurut Syafi iyyah hanya memperoleh tempat tinggal saja, dan tidak memperoleh nafkah. Dalam hal ini Syafi iyyah berbeda pendapat dengan Hanafiyyah.

Penalaran dan penafsiran terhadap nash merupakan bagian dari proses istinbât untuk menetapkan hukum. Penetapan hukum oleh para mujtahid walaupun menggunakan dalil yang sama tetapi sering terdapat perbedaan penafsiran. Dalam masalah nafkah iddah talak bain terdapat perbedaan pemahaman mujtahid dalam memahami Ayat 6 Surah ath-Talaq dan kehujjahan Hadis Fatimah binti Qais. Dengan demikian ikhtilaf ulama tidak berhenti walaupun ditemukan dalil dari Al-Quran dan Al-Sunnah pada suatu masalah yang sama. Permasalahan justru muncul ketika ditemukan dalil nash, tetapi berbeda dalam memahami dalil tersebut.

Adapun dalil nash dalam masalah nafkah iddah talak bain yang diperselisihkan penunjukan maknanya adalah Q.S. Ath-Thalaq ayat 6.

"Dan jika mereka (isteri-isteri yang sudah ditalaq) itu sedang hamil, Maka berikanlah kepada mereka nafkahnya hingga mereka bersalin, kemudian jika mereka menyusukan (anak-anak)mu untukmu Maka berikanlah kepada mereka upahnya."

Syafi iyyah menggunakan mafhum mukhalafah dalam memahami ayat di atas. Menurut Syafi iyyah dalam Surah ath-Talaq Ayat 6 Allah Swt, mewajibkan nafkah beserta kehamilan, maka menunjukkan bahwa nafkah tidak wajib ketika tidak ada kehamilan. Pemahaman tersebut dalam ushul fiqh disebut dengan mafhum mukhalafah, yaitu: mafhûm yang lafaz-nya menunjuk- kah bahwa hukum yang tidak disebutkan berbeda dengan hukum yang disebutkan. Atau bisa juga diartikan:

19 Kasjim Salenda, "Kehujjahan Istihsan dan Implikasinya dalam Istinbat Hukum,"Jurnal AdDaulah, Vol.1, No.2, Juni 2013, h. 3. 
hukum yang berlaku berdasarkan mafhûm yang berlawanan dengan hukum yang berlaku pada manthûq. ${ }^{20}$

Jumhur (mayoritas) ulama berpendapat bahwa mafhum mukhalafah dapat dijadikan hujjah hukum, jika memenuhi syarat, antara lain tidak bertentangan mafhum mantuq atau mafhum muwafaqah, hukum yang disebutkan dalam nash tidak sekedar untuk mendorong berbuat, dalil mantuq disebutkan secara terpisah dan persyaratan lainnya. ${ }^{21}$

Syafi iyyah berpandangan mafhum mukhalafah adalah hujjah sehingga suatu hukum dapat hilang dengan hilangnya syarat atau dengan hilangnya qayyid, selama tidak ada nash yang menunjukkan hukum sebaliknya. Dalam hal ini menurut Syafi iyyah kehamilan merupakan syarat atau qayid bagi wajibnya nafkah istri yang ditalak bain, yang berarti jika tidak ada kehamilan, maka tidak wajib memberi nafkah istri yang ditalak bain.

Syafi iyyah juga menggunakan hadis Ahad sebagai hujjah hukum. Hadis ahad yaitu: Hadis ahad ialah Hadis yang diriwayatkan oleh seorang atau lebih tetapi tidak sampai ke batas Hadis mutawatir. Dalam hal ini Syafi iyyah menerima Hadis Fatimah binti Qais yang berbunyi:

"Telah bercerita kepada kami Muhammad bin Mutsanna dan Ibnu Basyar, keduanya berkata: telah bercerita kepada kami Abdur Rahman bin Mahdi, ia berkata telah bercerita kepada kami Sufyan dari Salamah bin Kuhail dari Sya bi dari Fatimah binti Qais dari Nabi Saw, dalam masalah istri yang ditalak tiga, Beliau bersabda: "Tidak ada baginya (Fatimah binti Qais) tempat tinggal dan nafkah."

Hadis Fatimah binti Qais di atas dijadikan dasar oleh Syafi iyyah dalam menetapkan hukum tidak adanya nafkah bagi istri yang ditalak bain, jika istri tersebut tidak hamil. Menurut Syafi iyyah Hadis di atas dapat dijadikan dasar hukum karena memenuhi persyaratan keshahihan Hadis dan dapat berfungsi sebagai pen-takhsis terhadap makna umum pada Surah ath-Talaq Ayat 6. Pendapat Syafi iyyah tersebut merupakan pendapat jumhur ulama ushul fiqh yang berpendapat bahwa lafal umum dalam Al-Qur' an dapat di-takhsis oleh hadis ahad.

Adapun menurut Syafi iyyah, sebab wajibnya nafkah adalah sifat zaujiyyah, yaitu status perkawinan. Oleh karena itu menurut Syafi iyyah suami tidak wajib memberi nafkah istri dalam masa iddah talak bain, jika istri tersebut tidak hamil. Hal ini karena jatuhnya talak bain tidak memungkinkan lagi terjadinya rujuk, sehingga sifat zaujiyyah menjadi hilang. Hilangnya sifat zaujiyyah yang menjadi penyebab wajibnya nafkah, berakibat pada hilangnya musabbab, yaitu: wajibnya nafkah bagi istri pada masa iddah talak bain.

Dalam konteks hukum kontemporer, maka perlu analisis terhadap hasil ijtihad ulama terdahulu yang relevan dengan permasalahan hukum saat ini. Analisis tersebut bukan berarti melihat pendapat satu ulama sebagai satu-satunya solusi dan mengabaikan pendapat ulama lainnya, tetapi lebih kepada tarjih berdasarkan konteks situasi yang dihadapi. Hal ini sebagaimana dikatakan oleh Abdul Wahhab Khalaf bahwa lingkungan tempat tinggal mempunyai pengaruh dalam menentukan

${ }^{20}$ Amir Syarifudin, Ushul Fiqih Jilid II, (Jakarta: Kencana, 2011), h. 159.

21 Ibid, h. 167-168. 
kemaslahatan dan kebutuhan penting, mengunggulkan satu illat di atas illat lainnya karena kuatnya munasabah (kesesuaian) illat tersebut. ${ }^{22}$

Aspek sosio-kultural tidak dapat diabaikan sebagai faktor yang mempengaruhi hasil ijtihad ulama terdahulu dan tarjih terhadap pendapat yang relevan (munasabah) untuk dipilih saat ini. Dalam hal ini, peneliti lebih condong pendapat Hanafiyah yang mengatakan bahwa istri tetap berhak memperoleh tempat tinggal dan nafkah selama masa iddah talak bain, baik istri tersebut hamil, maupun tidak hamil. Hal ini karena menurut peneliti selama menjalani masa iddah, suami masih memiliki hak menahan istri di rumah yang disediakan suami. Selain itu proses menunggu dalam masa iddah juga berkaitan dengan kepentingan suami, yaitu memastikan tidak adanya kehamilan dari benih suami, sehingga lebih tepat jika istri yang ditalak bain tetap memperoleh nafkah.

\section{Simpulan}

Nafkah iddah merupakan bagian dari pembahasan fiqih munakahat, yang perinciannya tidak dijelaskan secara tegas dalam al-Qur'an dan Hadits. Hal ini yang menyebabkan terjadinya perbedaan pendapat di kalangan ulama madzhab. Perbedaan ini menjadi khazanah kekayaan intelektual di bidang furu' yang diakibatkan metode penggalian hukum dalam memahami dalil-dalil syara'. Hasil penelitian menunjukkan bahwa Syafi iyyah menggunakan mafhum mukhalafah sebagai metode istinbât dalam memahami Surah ath-Talaq Ayat 6 dan menggunakan Hadis ahad dari Fatimah binti Qais sebagai dasar tentang tidak adanya nafkah iddah talak bain bagi istri yang tidak hamil. Menurut Syafi iyyah, sebab wajibnya nafkah adalah sifat zaujiyyah, yaitu status perkawinan. Penggunaan mafhum mukhalafah oleh Syafiiyyah berpengaruh terhadap penetapan hukum. Menurut Syafi iyyah kehamilan merupakan syarat atau qayid bagi wajibnya nafkah istri yang ditalak bain, yang berarti jika tidak ada kehamilan, maka tidak wajib memberi nafkah istri yang ditalak bain.

\section{Referensi:}

Abdul Hadi Muthohhar, Pengaruh Mazhab Syafi i di Asia Tenggara, Semarang: Aneka Ilmu, 2003.

Abdul Manan, Aneka Masalah Hukum Perdata Islam di Indonesia, Jakarta: Kencana, 2017. Abdul Manan, Pembaruan Hukum Islam di Indonesia, Jakarta: Kencana, 2017.

Khallaf, Abdul Wahhab, Ijtihad dalam Syariat Islam, Terj. Rohidin Wahid, Jakarta: Pustaka Al-Kautsar, 2015.

Salim, Abu Malik Kamal bin as-Sayyid, Ensikiopedi Fiqih Wanita, Terj. Beni Sarbeni, Bogor: Pustaka Ibnu Katsir, 2009.

Rusyd, Abul Wahid Muhammad Ibnu, Bidayatul Mujtahid Wa Nihayatul Muqtasid, Terj. Imam Ghazali Said dan Ahmad Zaidun, Jakarta: Pustaka Amani, 2007.

Salam, Ahmad Nahrawi Abdus, Ensiklopedia Imam Syafi'i, al-Imam al-Syafi 'i Mazdhabihi al-Qadim wa al-Jadid), Terj. Usman Sya`roni, Jakarta: Mizan Publika, 2008.

${ }^{22}$ Abdul Wahhab Khallaf, Ijtihad dalam Syariat Islam, Terj. Rohidin Wahid, (Jakarta: Pustaka AlKautsar, 2015), h. 55. 
Amir Syarifudin, Ushul Fiqih Jilid II, Jakarta: Kencana, 2011.

Boedi Abdullah, Perkawinan dan Perceraian Keluarga Muslim, Bandung: Pustaka Setia, 2013.

Fauzi, Sejarah Hukum Islam, Jakarta: Kencana, 2018.

Ghufron A. Mas'adi, Pemikiran Fazlur Rahman tentang Metodologi Pembaharuan Hukum Islam, Jakarta: Raja Grafindo Persada, 1998.

Gus Arifin dan Sundus Wahidah, Ensikiopedia Fikih Wanita: Pembahasan Lengkap A-Z Fikih Wanita dalam Pandangan Empat Mazhab, Jakarta: Elex Media Komputindo, 2018.

Kasjim Salenda, "Kehujjahan Istihsan dan Implikasinya dalam Istinbat Hukum," Jurnal Ad-Daulah, Vol.1, No.2, Juni 2013.

Mughniyah, Muhammad Jawad, Fiqih lima mazhab: Ja'fari, Hanafi, Maliki, Syafi'i, Hambali, Terj. Masykur A.B., Jakarta: Lentera 2012.

Rahmawati, Istinbâț Hukum Teungku Muhammad Hasbi Ash-Shiddieqy, Yogvakarta: Deepublish, 2015.

Sabiq, Sayyid, Fiqih Sunnah, Terj. Nor Hasanuddin, Jakarta: Pena Pundi Aksara, 2006. Sirajuddin Abas, Sejarah dan Keagungan Madzhab Syafi'i, Jakarta: Pustaka Tarbiyah Baru, 2007. 